\title{
Conditionally Reprogrammed Human Normal Airway Epithelial Cells at ALI: A Physiological Model for Emerging Viruses
}

\author{
Xuefeng Liu $^{1,2}$ (D) Yuntao $\mathrm{Wu}^{3} \cdot$ Lijun Rong $^{4}$
}

Received: 16 April 2020 / Accepted: 22 May 2020/Published online: 17 June 2020

(c) Wuhan Institute of Virology, CAS 2020

\begin{abstract}
Cancer cell lines have been used widely in cancer biology, and as biological or functional cell systems in many biomedical research fields. These cells are usually defective for many normal activities or functions due to significant genetic and epigenetic changes. Normal primary cell yields and viability from any original tissue specimens are usually relatively low or highly variable. These normal cells cease after a few passages or population doublings due to very limited proliferative capacity. Animal models (ferret, mouse, etc.) are often used to study virus-host interaction. However, viruses usually need to be adapted to the animals by several passages due to tropism restrictions including viral receptors and intracellular restrictions. Here we summarize applications of conditionally reprogrammed cells (CRCs), long-term cultures of normal airway epithelial cells from human nose to lung generated by conditional cell reprogramming (CR) technology, as an ex vivo model in studies of emerging viruses. CR allows to robustly propagate cells from non-invasive or minimally invasive specimens, for example, nasal or endobronchial brushing. This process is rapid (2 days) and conditional. The CRCs maintain their differentiation potential and lineage functions, and have been used for studies of adenovirus, rhinovirus, respiratory syncytial virus, influenza viruses, parvovirus, and SARS-CoV. The CRCs can be easily used for airliquid interface (ALI) polarized 3D cultures, and these coupled CRC/ALI cultures mimic physiological conditions and are suitable for studies of viral entry including receptor binding and internalization, innate immune responses, viral replications, and drug discovery as an ex vivo model for emerging viruses.
\end{abstract}

Keywords Normal cells · Cell senescence · Conditional reprogramming · Physiological conditions · Functional models · Air-liquid interface (ALI) $\cdot$ Emerging viruses $\cdot$ SARS-CoVs

Xuefeng Liu

xuefeng.liu@georgetown.edu

1 Department of Pathology, Center for Cell Reprogramming, Georgetown University Medical Center, Washington, DC, USA

2 Department of Oncology, Lombardi Comprehensive Cancer Center, Georgetown University Medical Center, Washington, DC, USA

3 National Center for Biodefense and Infectious Diseases, School of Systems Biology, George Mason University, Manassas, VA 20110, USA

4 Department of Microbiology and Immunology, University of Illinoi at Chicago, Chicago, IL 60612, USA

\section{Conventional Cell Line Models for Virus Studies}

Emerging and re-emerging viral infections are becoming severe global public health problems in the current century. In February 2003, an outbreak of severe acute respiratory syndrome (SARS), caused by SARS coronavirus (SARS$\mathrm{CoV}$ ), was reported in Guangdong, China (Ksiazek et al. 2003). The SARS-CoV infected 8096 cases and 774 deaths worldwide. In March 2009 a novel influenza virus (H1N1pdm) emerged in the United States and Mexico. H1N1pdm obtained the capacity to transmit in humans and quickly spread to more than 214 countries (Hendrickson and Matthay 2013). Thereafter the H1N1 infection became a seasonal virus circulating over the world (Dawood et al. 2009). Middle East respiratory syndrome (MERS) coronavirus was isolated from patients who developed acute 
pneumonia and renal failure in 2012 from Saudi Arabia (Zaki et al. 2012). One big secondary outbreak with 186 confirmed cases was in South Korea in 2015. Up to January 2020 , more than 2500 confirmed cases were reported with a case fatality of $34.4 \%$ (WHO 2019). In December 2019, a novel coronavirus, SARS-CoV-2 caused an outbreak of acute pneumonia in Wuhan City of China (Zhou $\mathrm{P}$ et al. 2020). The current animal models for study of SARS-CoVs include African green monkeys, macaques, ferret, and mice (Kong et al. 2009; Smits et al. 2011). These in vivo models are useful for studying many important questions, for example, local or systemic pathogenic changes, immune response, and drug metabolism and in vivo efficacy. However, these animal models have limitations due to species difference. The viral tropism correlates to expression of viral receptor(s) on the surface of host cells and intracellular restriction as well. Cancer cell lines have been used widely for biological or functional cell systems in many other fields (Agarwal and Rimm 2012; Barretina et al. 2012; Palechor-Ceron et al. 2019). These cells are defective for many functions of normal human cells because of significant genetic and epigenetic changes compared to the normal tissues. However, primary cell yields and viability from any original tissue specimens are often relatively low or highly variable. These normal cells cease at a few passages because of very limited proliferative capacity in vitro. It has been extremely difficult for decades to generate and maintain normal cell lines. Several exogenous immortalization approaches have been used to establish primary cell lines from variety of tissue types. For example, viral oncogenes such as SV40 large T antigen or the human papillomavirus (HPV) E6/E7 proteins can bypass the cell senescence block through interfering with p53 and $\mathrm{Rb}$ regulatory pathways (Liu et al. 2005; Liu et al. 2007; Liu et al. 2008; Cid Arregui et al. 2012; Klingelhutz and Roman 2012; Ghittoni et al. 2015). Expression of exogenous cellular genes (hTERT, c-Myc, cdk4, etc.) or inactivation of cellular tumor repressors (p53, pRB, etc.) can be widely used to immortalize primary human normal cells, which leads to disrupted cell differentiation or loss of tissue type-specific functions (Liu et al. 2012).

We observed that two classes of functions are required for cell immortalization by HPV E6 and E7: telomerase activation and actin cytoskeleton alterations ( $\mathrm{Fu}$ et al. 2003; Charette and McCance 2007; Liu et al. 2007; Liu et al. 2008; Yue et al. 2011; Klingelhutz and Roman 2012). We also noted that feeder cells and altered molecular pathways activate telomerase (Fu et al. 2003; Liu et al. 2008; Liu et al. 2009; Klingelhutz and Roman 2012; Liu et al. 2012), and a Rho-Kinase inhibitor, Y-27632, disrupts the actin cytoskeleton and inactivate Rho (Chapman et al. 2010; Liu et al. 2012). Unexpectedly, combination of feeder layers and Y-27632 allows to rapidly establish both normal and tumor cell cultures from non-keratinocyte tissues (Liu et al. 2012; Suprynowicz et al. 2012; PalechorCeron et al. 2013; Liu et al. 2017). We also demonstrated that the effect of the combined co-culture condition is rapid ( 2 days), and the whole cell populations are shifted or reprogrammed rather than a clone selection as conventional cancer cell lines (Liu et al. 2012; Suprynowicz et al. 2012). These cell cultures stop proliferating if one of the conditions (Y-27632 or feeder layer) is not met. We termed this culture method and resulting cells as "conditional reprogramming (CR)" and "conditionally reprogrammed cells (CRC)", respectively (Liu et al. 2012; Suprynowicz et al. 2012; Palechor-Ceron et al. 2013; Liu et al. 2017; Palechor-Ceron et al. 2019). Indeed, organoids (Weeber et al. 2017; Puca et al. 2018; Sachs et al. 2018; Mullenders et al. 2019; Xinaris 2019) and CR technologies have been widely used in cancer biology and regeneration fields. They both have been recognized as the key new technologies by NCI (National Cancer Institute) precision oncology (https://ocg.cancer.gov/programs/hcmi/research) (Friedman et al. 2015; Senft et al. 2017), which are used for HCMI (human cancer model initiatives) program launched during 2019 annual AACR) (https://www.atcc.org/en/Pro ducts/Cells_and_Microorganisms/HCMI.aspx?utm_id\&e quals;t1802043811). Table 1 lists properties of these cell models. In this review, we will highlight roles of CRC and coupled air-liquid interface (ALI) system in studies of emerging viruses.

\section{CR Methodology}

Primary airway epithelial cells can be obtained from airway tract using non-invasive or minimally invasive techniques, nasal brushing, nasorophynx swaps, induced sputum sample collection, bronchiolar lavage, endobronchial brushing or biopsy. After CR technology was established in 2012, the $\mathrm{CR}$ protocol has been proven to easily establish patientderived normal and cancer cell cultures without genetic manipulation (Liu et al. 2012; Palechor-Ceron et al. 2013; Liu et al. 2017). Originally, the CR used irradiated mouse fibroblast cells (swiss mouse 3T3, J2 clone) and the Rhoassociated kinase inhibitor (Y-27632) to propagate epithelial cells (Liu et al. 2012; Palechor-Ceron et al. 2013; Liu et al. 2017). A few improvements have been used to simplify protocols using $\mathrm{J} 2$ conditioned medium (Liu et al. 2012; Palechor-Ceron et al. 2013; Liu et al. 2017), hypoxia condition $\left(1 \%-2 \% \mathrm{O}_{2}\right)$ (Peters-Hall et al. 2018), and combination with dual TGF-beta/SMAD inhibition (Mou et al. 2016; Zhang C et al. 2018). CR technology is simple and cheap since there is no need for expensive reagents as matrigel for organoids, robust since $1 \times 10^{6}$ cells can be generated from a needle biopsy within 7 days, and rapid 
Table 1 Comparison of ex vivo cell models.

\begin{tabular}{llll}
\hline & Conventional cell lines & Organoids & CRC \\
\hline Sample size & Surgical & Small to big & Tiny to big \\
Timing & $1-5$ months & $1-5$ weeks & $1-10$ days \\
Success rate of initiation $(\%)$ & $(0-10)$ & $++(5-80)$ & $+++(50-100)$ \\
Rapid expansion & +++ & ++ & +++ \\
Karyotypic stability & + & ++ & ++ \\
3D growth & - & ++ & - \\
Genetic manipulation & +++ & ++ & ++ \\
Low throughput drug screens & +++ & ++ & +++ \\
High throughput drug screens & +++ & ++ & +++ \\
Heterogeneity & - & ++ & ++ \\
Cell biology & + & +++ & +++ \\
Cost & + & ++ & + \\
\hline
\end{tabular}

“_" “+" “++" and "+++" indicate "unsuitable or not applicable", "possible", "suitable", and "best" for the aspects or applications except for "cost". "+" and "++" represent "low" and "high" for in "cost" line, respectively. since the whole populations of cells can be reprogrammed within 2 days instead of clonal selection. Figure 1 shows a diagram of normal cell cultures in CR conditions and 3D (ALI and non-iPS organoids) conditions for ex vivo models of airway epithelial cells.

\section{CRCs Maintain Differentiation Potential and Lineage Functions of Normal Airway Epithelial Cells}

CR allows the rapid generation of multi-lineage cell cultures (conditionally reprogrammed cells, CRC) from many different normal epithelial tissues, as well as tumors derived from these sites (Liu et al. 2012; Suprynowicz et al. 2012; Palechor-Ceron et al. 2013; Liu et al. 2017; Palechor-Ceron et al. 2019). Normal cell lines retain their normal karyotype and growth properties, and tumor cells retain their tumorigenic potential (Liu et al. 2012; Suprynowicz et al. 2012; Palechor-Ceron et al. 2013; Borodovsky et al. 2017; Liu et al. 2017; Yuan et al. 2017;
Alkhilaiwi et al. 2018; Correa et al. 2018; Palechor-Ceron et al. 2019). Interestingly, generation of CRC from normal tissue is reversible, and manipulating CR conditions allows the cells to differentiate normally (Suprynowicz et al. 2012; Liu et al. 2017). For example, when CRC from skin epithelium or tracheal epithelium are placed in an ALI culture system, the skin cells form a well-differentiated stratified squamous epithelium, whereas the tracheal cells form a ciliated airway epithelium.

\section{CRCs at ALI}

ALI (Air-Liquid interface) culture (Fig. 2) of CR airway cells is uniquely suited as a model for in vitro infection studies. This is due to the ability of ALI cultures to faithfully recapitulate key characteristics of the in vivo airway. For example, ALI cultures exhibit relevant proportions of airway cell types, appropriate cellular polarization and junctional properties, dynamic physiologic processes such as mucus secretion and coordinated ciliary beating, and

Fig. 1 Workflow for ex vivo models of human normal airway epithelial cells.

UPPER AIRWAY
Nasal cavity
Oral cavity
Nasopharynx
Oropharynx
Larynx
LOWER AIRWAY
Trachea
Bronchi
Alveolar duct

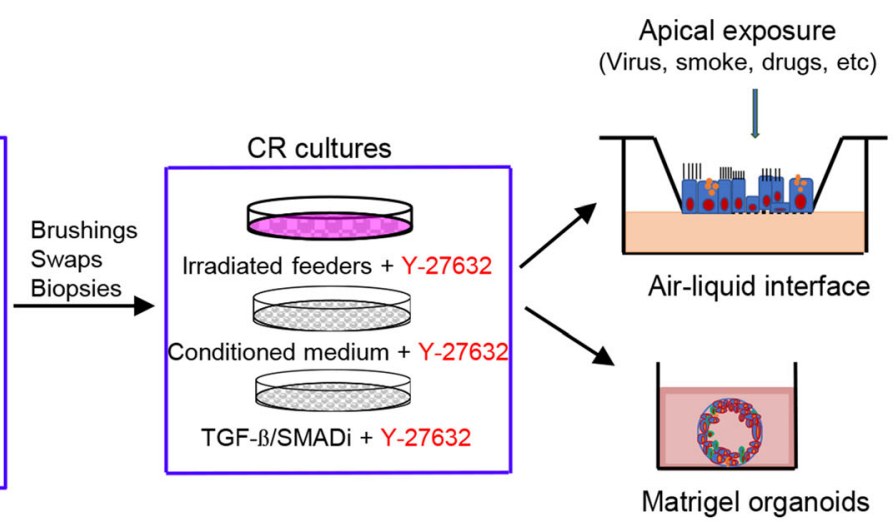




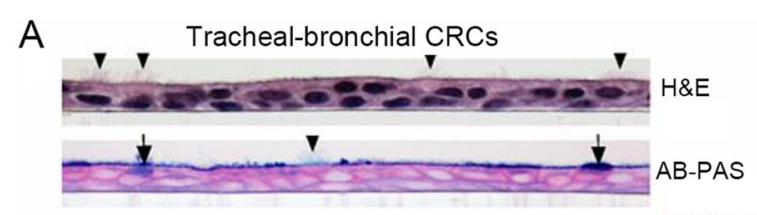

B Confocal immunofluorescence of tracheal-bronchial CRCs

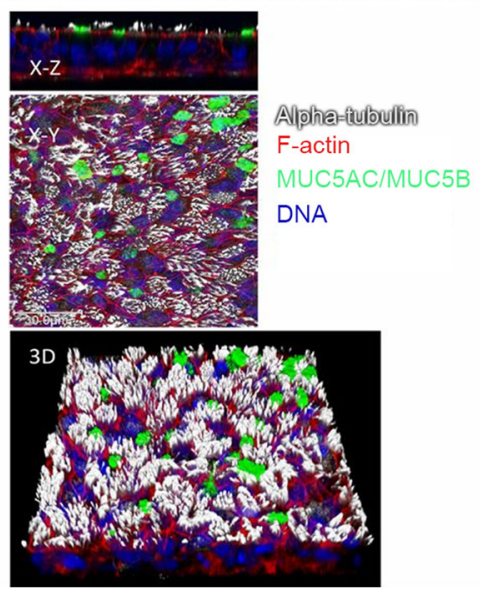

Fig. 2 Air-liquid interface (ALI) differentiation cultures of normal airway conditionally reprogrammed cells (CRCs). A Histological sections of ALI cultures of CRCs. Sections were stained with H\&E or a combination of alcian blue and periodic acid-Schiff reaction (ABPAS). Note the presence of ciliated cells (arrowheads) and mucusproducing cells (arrows). B Confocal microscopy of trachealbronchial CRCs that were differentiated in ALI culture, fixed and fluorescently labeled with phalloidin (F-actin), Hoechst dye 33342 (DNA), or antibodies demonstrating the presence of cilia (alphatubulin) and mucins 5AC and 5B (MUC5AC/MUC5B). An $X_{-}$ $Z$ cross-section, extended focus $X-Y$ view, and corresponding threedimensional (3D) view are shown. (adapted from PNAS (https:// www.pnas.org/page/authors/licenses), (Suprynowicz et al. 2012).

physiological expression and subcellular localization of characteristic proteins bearing species-specific sequences.

\section{CRCs/ALI: An Ex Vivo Models for Virus Infections}

To date, CR by itself or in combination with ALI cultures have been used in studies of host defense and viral infections, drug screening and toxicity testing, wound healing/repair, gene therapies as ex vivo preclinical models for lung cancer, chronic obstructive pulmonary disease, cystic fibrosis, and asthma (Yuan et al. 2012; Bove et al. 2014; Crystal et al. 2014; Saenz et al. 2014; Chu et al. 2015b; Feng et al. 2015; Kotha et al. 2015; Walters et al. 2015; Alamri et al. 2016; Beglyarova et al. 2016; Butler et al. 2016; Ellis et al. 2016; Papapetrou 2016; Reynolds et al. 2016; Borodovsky et al. 2017; Gentzsch et al. 2017; Jensen et al. 2017; Li et al. 2017; Mahajan et al. 2017; Martinovich et al. 2017; Wolf et al. 2017; Yu et al. 2017; Yuan et al. 2017; Alkhilaiwi et al.
2018; Boström et al. 2018; Brewington et al. 2018; Correa et al. 2018; Jin et al. 2018; LaRanger et al. 2018; Mimoto et al. 2018; Moorefield et al. 2018; Peters-Hall et al. 2018; Shay et al. 2018; Wang et al. 2018; Zhang Z et al. 2018; Alkhilaiwi et al. 2019; Jiang et al. 2019; Krawczyk et al. 2020; Liu 2019; Martini et al. 2019; Mondal et al. 2019; Nicolas et al. 2019; Palechor-Ceron et al. 2019; Su et al. 2019; Chai et al. 2020). Compared to organoids (close 3D cultures) shown in Fig. 1 (right lower panel), ALI system is much easier for virology studies because of an open apical area for infections or viral inoculations (Fig. 3). Here we will focus our discussion on applications of this physiological system in respiratory virus infections. Figure 3 shows many aspects of studies of emerging viruses.

Roberts et al. collected samples from paired nasal and bronchial brushings and cultured and expanded nasal and bronchial epithelial cells using CR condition (irradiated 3T3 fibroblasts in presence of Y-27632) (Roberts et al. 2018). Passaged cells were then put onto collagen coated transwells in 12 well plates for ALI culture. They found that viral infection in both cell types increased the expression of IP-10 (interferon gamma-induced protein 10), although the increase was only significant in the ALI culture, with combining rhinovirus infection and IL-13 treatment (Roberts et al. 2018). Kotha et al. showed that the level of the apical adenovirus receptor $\left(\mathrm{CAR}^{\mathrm{Ex} 8}\right)$ and physiologically relevant levels of IL-8 and neutrophils (components of the innate immune system) enhanced entry of adenovirus in polarized human airway epithelia (Kotha et al. 2015). Jonsdottir et al. established CRC and ALI cultures from both upper and lower airway to study the host innate immune response to human coronavirus 229E (HCoV-229E) and human respiratory syncytial virus (RSV) after gene manipulations (Jonsdottir et al. 2019). It is well known that autonomous parvovirus replication depends on the $\mathrm{S}$ phase of the host cells. Interestingly, Deng et al. (2016) reported for the first time parvovirus DNA replicated in non-dividing cells autonomously. They first established CR cells and ALI cultures (non-dividing airway epithelial cells) and inoculated ALI with human parvovirus $\mathrm{HBoV} 1$. Their results demonstrated that $\mathrm{HBoV} 1$ infection of ALI cultures induces a DNA damage response (DDR), thereby facilitating viral genome amplification. They also discovered that $\mathrm{Y}$ - family DNA repair polymerases, Pol $\eta$ and Pol $\kappa$, are involved in HBoV1 genome amplification in ALI system. This is the first report to show that parvovirus DNA replicates in non-dividing cells autonomously. Zhu et al. studied HSV-2 infection in CR and ALI cultured normal vaginal epithelial cells (Zhu et al. 2017). Fink et al. also established CR cells from routine vaginal repair surgeries or hysterectomies and studied antiviral drug (Arbidol) Inhibition of Zika virus (Fink et al. 2018). Finally, Imai-Matsushima et al. generated long-term 
Fig. 3 Potential applications of CR/ALI cultures in emerging viruses.

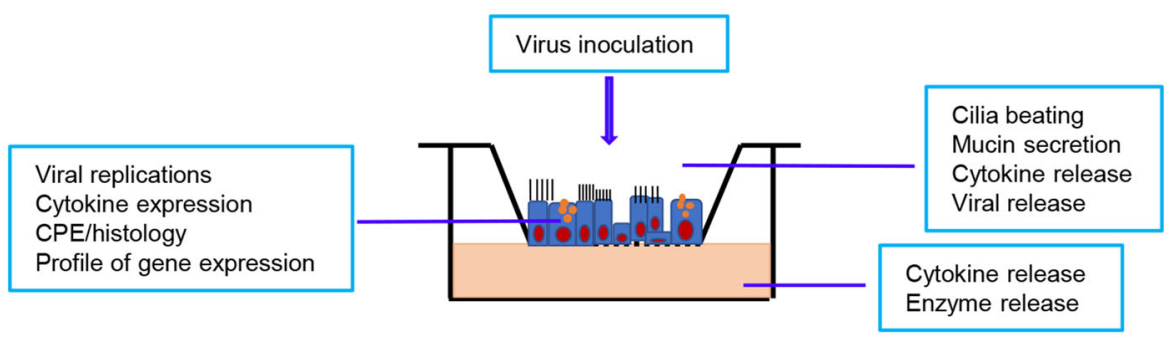

culture of distal airway epithelial cells and differentiated alveolar epithelial cells that are suited for influenza virus study (Imai-Matsushima et al. 2018).

\section{CRCs/ALI: Potential Applications in SARS- CoV-2 and Coronavirus Disease 2019 (COVID-19)}

On Jan. 30 and March 11, 2020, the International Health Regulations Emergency Committee World Health Organization (WHO) declared the COVID-19 or SARS-CoV-2 infection outbreak as a "public health emergency of international concern", and characterized COVID-19 as a pandemic, respectively (WHO 2020). COVID-19 cases have ranged from very mild (including asymptomatic), mild, moderate, severe, and critical severe including illness resulting in death (Lu et al. 2020; Singhal 2020; Wang et al. 2020; Wu and McGoogan 2020; Yang S et al. 2020; Yang X et al. 2020; Ye et al. 2020; Zhang et al. 2020; Zhou C et al. 2020; Zhou F et al. 2020; Zou et al. 2020). COVID-19 common symptoms include fever, cough and shortness of breath. Muscle pain, sputum production and sore throat are less common (Lu et al. 2020; Singhal 2020; Wang et al. 2020; Wu and McGoogan 2020; Yang S et al. 2020; Yang X et al. 2020; Ye et al. 2020; Zhang et al. 2020; Zhou C et al. 2020; Zhou F et al. 2020; Zou et al. 2020). While the majority of cases result in mild symptoms, some progress to severe pneumonia and multi-organ failure including lung, heart, and kidney (Lu et al. 2020; Singhal 2020; Wang et al. 2020; Wu and McGoogan 2020; Yang S et al. 2020; Yang X et al. 2020; Ye et al. 2020; Zhang et al. 2020; Zhou C et al. 2020; Zhou F et al. 2020; Zou et al. 2020). The rate of deaths per number of diagnosed cases is estimated to be $3.4 \%$ but varies by age and other health conditions (Lu et al. 2020; Singhal 2020; Wang et al. 2020; Wu and McGoogan 2020; Yang S et al. 2020; Yang X et al. 2020; Ye et al. 2020; Zhang et al. 2020; Zhou C et al. 2020; Zhou F et al. 2020; Zou et al. 2020). The mechanisms how SARS-CoV-2 infects human airway epithelial cells and also causes severe multi-organ failure are largely unknown. Generally speaking, early stage of COVID-19 or cases with very mild (including asymptomatic), mild symptoms are usually due to rapid replication of viruses at local areas, innate response of the host cells and local immune-response ( $\operatorname{Ig} \mathrm{A})$. Severe cases with multi-organ injury are usually due to possible viral replications in the target organs and immunopathogenic injuries (including cytokine storm or antibody dependent enhancement). Recently, two reports demonstrated that large amounts of SARS-CoV-2 were detected in the upper airway and saliva (To et al. 2020; Zou et al. 2020).

SARS-CoV-2 and SARS-CoV share the same functional host-cell receptor ACE2 (Hoffmann et al. 2020; Walls et al. 2020; Wan et al. 2020; Wrapp et al. 2020; Zhou P et al. 2020) and sequence analysis reveals that SARS-CoV-2 possesses crucial amino acid residues for ACE2 binding (Hoffmann et al. 2020). ACE2 predominantly expresses in vascular endothelial cells, kidney and heart tissues, small intestine, and testes (Hamming et al. 2004). The distribution of ACE2 in human tissues does not seem to correlate with diseases with COVID-19, while this may help explain why severe cases with COVID-19 have multi-organ failure including heart and kidney. It is important to understand body site-specific or tissue-specific viral replication, innate immune response, and infectivity. Two recent reports demonstrated that large amounts of SARS-CoV-2 were found in the upper airway and saliva as we described above (To et al. 2020; Zou et al. 2020), where ACE2 is not expressed or expresses at very low levels. Wolfel et al. performed a dynamic viral analysis of nine COVID-19 patients, they showed active virus replication in upper airway tissues. Virus shedding at pharynx was very high at the first week of symptoms, the peak was at $7.11 \times 10^{8}$ RNA copies per throat swab at day 4 . SARS-CoV-2 viruses were readily cultured from throat- and lung-derived samples, but not from stool samples with high viral RNA. Viral load was declined after 7 days of symptoms (Wolfel et al. 2020). A ferret model of SASR-CoV-2 infection and transmission was established recently (Kim et al. 2020), which can recapitulate some aspects of human COVID-19 disease. SARSCoV-2-infected ferrets shed virus in nasal washes, saliva, urine, and feces up to 8 days after infection. Viral antigens were also detected in several tissues, as nasal cavity, trachea, lung, and intestine. This ferret model represents an animal model of SARS-CoV-2 infection and transmission, may 
facilitate to develop COVID-19 therapeutics and vaccine as well. However, distribution of ACE2 and viral replication in different organs or tissues, or possible other receptors or coreceptors in this model need to be further determined. Another study also demonstrated that SARS-CoV-2 may replicate well in ferrets and cats, but poorly in dogs, pigs, chickens, and ducks (Shi et al. 2020). These inconsistences suggest possible alternative receptors or co-receptors on the surface of the target cells in different tissues. A study by Blanco-Melo et al. suggests that human alveolar adenocarcinoma cells (A549) are able to support viral replication of SARS-CoV-2, RSV and influenza A virus, despite undetectable levels of ACE2 and TMPRSS2, the putative receptor and protease for SARS-CoV-2 entry (Blanco-Melo et al. 2020). To solve these problems, we will need comprehensive studies of tissue staining of viral antigens and cellular proteins from COVID-19 patients. Then, human related physiological models are urgently needed to investigate these questions and for functional validation. In agreement with these arguments, an early study on SARS$\mathrm{CoV}$ indicates that host cell differentiation or polarized epithelium and expression of ACE2 are both important for the susceptibility of human airway epithelia to SARS-CoV viral infection (Jia et al. 2005; Tseng et al. 2005). Indeed, ALI cultures of human airway epithelial cells (HAEs) have also been used for functional drug screening of SARS-CoV and SARS-CoV-2 (Sheahan et al. 2017; Sheahan et al. 2020). Since CRCs are stable resources for normal functional airway cells, CRCs/ALI cultures will facilitate these studies and development of novel therapeutics as a functional and biological system.

\section{Advantage and Limitations}

As we discussed above, $\mathrm{CR}$ is a rapid, robust and sufficient way to obtain large amount of normal airway cells from non-invasive and minimal human samples, and CRCs from respiratory tract maintain their lineage functions. ALI provides a unique environment to mimic "in vivo" physiological conditions. Thus, CRC/ALI will be appropriate for studies of viral entry to the nature host cells, innate immune response of the host cells, and tests of anti-viral and immune (innate) modulators (Fig. 3). This will be a unique biological or functional cell system for population or health disparity studies since there is no biological cell model available in the field. Since CRCs can be easily genetically manipulated with overexpression of exogenous genes, shRNAs, or CRISPR technologies (Chu et al. 2015a; Fenini et al. 2018), CRC/ALI should be a unique system for both phenotypical and mechanism studies for human viral diseases. Although CRCs alone can be used for rapid and high throughput screening, combination CRC and ALI will take much longer time and need further development for high throughput studies. Compare to the current permissive cancer cell lines or animal derived permissive cell lines, CRC/ALI for virus studies requires experienced performance, higher work load and cost. Thus, CRC/ALI will serve as a human-relevant, physiological system for emerging viruses in addition the current cell lines and animal models.

\section{Conclusions}

Because of limitations of current cell line and animal models, there is an urgent need of human physiological cell models for studies of emerging viruses. Here we summarized establishment of long term cultures for human normal airway epithelial cells from nose to lung using CR and coupled ALI technologies and their applications as an ex vivo model for emerging viruses. As a great addition to the current cell lines and animal models, CRC/ALI system will facilitate studies of viral entry including receptors and internalization, innate immune responses, viral replications, and drug discovery.

Acknowledgements This work was in part support by a GUMC COVID-19 grant (to XL), and the support from Center for Cell Reprogramming, GUMC.

\section{Compliance with Ethical Standards}

Conflict of interest The authors declare that they have no conflict of interest.

Animal and Human Rights Statement This article does not contain any studies with human or animal subjects performed by any of the authors.

Disclosure Several patents for conditional reprogramming technology has been awarded to Georgetown University by the United States Patent Office. The license for this technology has been given to Propagenix for commercialization. The inventor, X.L., and Georgetown University receive potential royalties and payments from Propagenix.

\section{References}

Agarwal S, Rimm DL (2012) Making every cell like HeLa a giant step for cell culture. Am J Pathol 180:443-445

Alamri AM, Kang K, Groeneveld S, Wang W, Zhong X, Kallakury B, Hennighausen L, Liu X, Furth PA (2016) Primary cancer cell culture: mammary-optimized vs conditional reprogramming. Endocr Relat Cancer 23:535-554

Alkhilaiwi F, Wang L, Zhou D, Raudsepp T, Ghosh S, Paul S, Palechor-Ceron N, Brandt S, Luff J, Liu X, Schlegel R, Yuan H (2018) Long-term expansion of primary equine keratinocytes that maintain the ability to differentiate into stratified epidermis. Stem Cell Res Ther 9:181 
Alkhilaiwi F, Paul S, Zhou D, Zhang X, Wang F, Palechor-Ceron N, Wilson K, Guha R, Ferrer M, Grant N, Thomas C, Schlegel R, Yuan H (2019) High-throughput screening identifies candidate drugs for the treatment of recurrent respiratory papillomatosis. Papillomavirus Res 8:100181

Barretina J, Caponigro G, Stransky N, Venkatesan K, Margolin AA, Kim S, Wilson CJ, Lehar J, Kryukov GV, Sonkin D, Reddy A, Liu M, Murray L, Berger MF, Monahan JE, Morais P, Meltzer J, Korejwa A, Jane-Valbuena J, Mapa FA, Thibault J, Bric-Furlong E, Raman P, Shipway A, Engels IH, Cheng J, Yu GK, Yu J, Aspesi P Jr, de Silva M, Jagtap K, Jones MD, Wang L, Hatton C, Palescandolo E, Gupta S, Mahan S, Sougnez C, Onofrio RC, Liefeld T, MacConaill L, Winckler W, Reich M, Li N, Mesirov JP, Gabriel SB, Getz G, Ardlie K, Chan V, Myer VE, Weber BL, Porter J, Warmuth M, Finan P, Harris JL, Meyerson M, Golub TR, Morrissey MP, Sellers WR, Schlegel R, Garraway LA (2012) The cancer cell line encyclopedia enables predictive modelling of anticancer drug sensitivity. Nature 483:603-607

Beglyarova N, Banina E, Zhou Y, Mukhamadeeva R, Andrianov G, Bobrov E, Lysenko E, Skobeleva N, Gabitova L, Restifo D, Pressman M, Serebriiskii IG, Hoffman JP, Paz K, Behrens D, Khazak V, Jablonski SA, Golemis EA, Weiner LM, Astsaturov I (2016) Screening of conditionally reprogrammed patient-derived carcinoma cells identifies ERCC3-MYC interactions as a target in pancreatic cancer. Clin Cancer Res 22:6153-6163

Blanco-Melo D, Nilsson-Payant BE, Liu W-C, Møller R, Panis M, Sachs D, Albrecht RA, tenOever BR (2020) SARS-CoV-2 launches a unique transcriptional signature from in vitro, ex vivo, and in vivo systems. bioRxiv. https://doi.org/10.1101/ 2020.03.24.004655:2020.2003.2024.004655

Borodovsky A, McQuiston TJ, Stetson D, Ahmed A, Whitston D, Zhang J, Grondine M, Lawson D, Challberg SS, Zinda M, Pollok BA, Dougherty BA, D'Cruz CM (2017) Generation of stable PDX derived cell lines using conditional reprogramming. Mol Cancer 16:177

Boström P, Kettunen K, Lamminen T, Heinosalo T, West G, Poutanen M, Rantala J, Taimen P (2018) 462 - High-throughput drug screening using conditionally reprogrammed patientderived cell lines in bladder cancer. European Urology Supplements 17:e662

Bove PF, Dang H, Cheluvaraju C, Jones LC, Liu X, O’Neal WK, Randell SH, Schlegel R, Boucher RC (2014) Breaking the in vitro alveolar type II cell proliferation barrier while retaining ion transport properties. Am J Respir Cell Mol Biol 50:767-776

Brewington JJ, Filbrandt ET, LaRosa FJ 3rd, Moncivaiz JD, Ostmann AJ, Strecker LM, Clancy JP (2018) Generation of human nasal epithelial cell spheroids for individualized cystic fibrosis transmembrane conductance regulator study. J Vis Exp 11:57492

Butler CR, Hynds RE, Gowers KHC, Brown JM, Lee DDH, Teixeira VH, Hamilton NJ, Birchall MA, O'Callaghan C, Janes SM (2016) Co-culture-expanded human basal epithelial stem cells for application in tracheal tissue engineering. The Lancet 387:S23

Chai J, Han L, Zhang J, Han D, Zou L, Zhu Z, Zhao Y, Guo H (2020) Conditional reprogramming inducing clinical cells proliferation: new research tools in tumor and inflammatory-related diseases. Curr Pharm Des. https://doi.org/10.2174/1381612826666 200316155252

Chapman S, Liu X, Meyers C, Schlegel R, McBride AA (2010) Human keratinocytes are efficiently immortalized by a Rho kinase inhibitor. J Clin Invest 120:2619-2626

Charette ST, McCance DJ (2007) The E7 protein from human papillomavirus type 16 enhances keratinocyte migration in an Akt-dependent manner. Oncogene 26:7386-7390

Chu HW, Rios C, Huang C, Wesolowska-Andersen A, Burchard EG, O'Connor BP, Fingerlin TE, Nichols D, Reynolds SD, Seibold
MA (2015) CRISPR-Cas9-mediated gene knockout in primary human airway epithelial cells reveals a proinflammatory role for MUC18. Gene Ther 22:822-829

Cid Arregui A, Gariglio P, Kanda T, Doorbar J (2012) Oncogenic human papillomaviruses: high-risk human papillomaviruses: towards a better understanding of the mechanisms of viral transformation, latency and immune-escape. Open Virol $\mathrm{J}$ 6:160-162

Correa BRS, Hu J, Penalva LOF, Schlegel R, Rimm DL, Galante PAF, Agarwal S (2018) Patient-derived conditionally reprogrammed cells maintain intra-tumor genetic heterogeneity. Sci Rep 8:4097

Crystal AS, Shaw AT, Sequist LV, Friboulet L, Niederst MJ, Lockerman EL, Frias RL, Gainor JF, Amzallag A, Greninger P, Lee D, Kalsy A, Gomez-Caraballo M, Elamine L, Howe E, Hur W, Lifshits E, Robinson HE, Katayama R, Faber AC, Awad MM, Ramaswamy S, Mino-Kenudson M, Iafrate AJ, Benes CH, Engelman JA (2014) Patient-derived models of acquired resistance can identify effective drug combinations for cancer. Science 346:1480-1486

Dawood FS, Dalton CB, Durrheim DN, Hope KG (2009) Rates of hospitalisation for acute respiratory illness and the emergence of pandemic (H1N1) 2009 virus in the Hunter New England Area Health Service. Med J Aust 191:573-574

Deng X, Yan Z, Cheng F, Engelhardt JF, Qiu J (2016) Replication of an autonomous human parvovirus in non-dividing human airway epithelium is facilitated through the DNA damage and repair pathways. PLoS Pathog 12:e1005399

Ellis L, Ku S, Li Q, Azabdaftari G, Seliski J, Olson B, Netherby CS, Tang DG, Abrams SI, Goodrich DW, Pili R (2016) Generation of a C57BL/6 MYC-Driven mouse model and cell line of prostate cancer. Prostate 76:1192-1202

Feng W, Guo J, Huang H, Xia B, Liu H, Li J, Lin S, Li T, Liu J, Li H (2015) Human normal bronchial epithelial cells: a novel in vitro cell model for toxicity evaluation. PLoS One 10:e0123520

Fenini G, Grossi S, Contassot E, Biedermann T, Reichmann E, French LE, Beer HD (2018) Genome editing of human primary keratinocytes by CRISPR/Cas9 reveals an essential role of the NLRP1 inflammasome in UVB sensing. J Invest Dermatol 138:2644-2652

Fink SL, Vojtech L, Wagoner J, Slivinski NSJ, Jackson KJ, Wang R, Khadka S, Luthra P, Basler CF, Polyak SJ (2018) The antiviral drug arbidol inhibits zika virus. Sci Rep 8:8989

Friedman AA, Letai A, Fisher DE, Flaherty KT (2015) Precision medicine for cancer with next-generation functional diagnostics. Nat Rev Cancer 15:747-756

Fu B, Quintero J, Baker CC (2003) Keratinocyte growth conditions modulate telomerase expression, senescence, and immortalization by human papillomavirus type 16 E6 and E7 oncogenes. Cancer Res 63:7815-7824

Gentzsch M, Boyles SE, Cheluvaraju C, Chaudhry IG, Quinney NL, Cho C, Dang H, Liu X, Schlegel R, Randell SH (2017) Pharmacological rescue of conditionally reprogrammed cystic fibrosis bronchial epithelial cells. Am J Respir Cell Mol Biol 56:568-574

Ghittoni R, Accardi R, Chiocca S, Tommasino M (2015) Role of human papillomaviruses in carcinogenesis. Ecancermedicalscience 9:526

Hamming I, Timens W, Bulthuis ML, Lely AT, Navis G, van Goor H (2004) Tissue distribution of ACE2 protein, the functional receptor for SARS coronavirus. A first step in understanding SARS pathogenesis. J Pathol 203:631-637

Hendrickson CM, Matthay MA (2013) Viral pathogens and acute lung injury: investigations inspired by the SARS epidemic and the 2009 H1N1 influenza pandemic. Semin Respir Crit Care Med $34: 475-486$ 
Hoffmann M, Kleine-Weber H, Schroeder S, Kruger N, Herrler T, Erichsen S, Schiergens TS, Herrler G, Wu NH, Nitsche A, Muller MA, Drosten C, Pohlmann S (2020) SARS-CoV-2 cell entry depends on ACE2 and TMPRSS2 and is blocked by a clinically proven protease inhibitor. Cell. https://doi.org/10. 1016/j.cell.2020.02.052

Imai-Matsushima A, Martin-Sancho L, Karlas A, Imai S, Zoranovic T, Hocke AC, Mollenkopf HJ, Berger H, Meyer TF (2018) Long-term culture of distal airway epithelial cells allows differentiation towards alveolar epithelial cells suited for influenza virus studies. EBioMedicine 33:230-241

Jensen TJ, Foster C, Sayej W, Finck CM (2017) Conditional reprogramming of pediatric human esophageal epithelial cells for use in tissue engineering and disease investigation. J Vis Exp. https://doi.org/10.3791/55243

Jia HP, Look DC, Shi L, Hickey M, Pewe L, Netland J, Farzan M, Wohlford-Lenane C, Perlman S, McCray PB Jr (2005) ACE2 receptor expression and severe acute respiratory syndrome coronavirus infection depend on differentiation of human airway epithelia. J Virol 79:14614-14621

Jiang S, Wang J, Yang C, Tan R, Hou J, Shi Y, Zhang H, Ma S, Wang J, Zhang M, Philips G, Li Z, Ma J, Yu W, Wang G, Wu Y, Schlegel R, Wang H, Cao S, Guo J, Liu X, Dang Y (2019) Continuous culture of urine-derived bladder cancer cells for precision medicine. Prot Cell 10:902-907

Jin L, Qu Y, Gomez LJ, Chung S, Han B, Gao B, Yue Y, Gong Y, Liu X, Amersi F, Dang C, Giuliano AE, Cui X (2018) Characterization of primary human mammary epithelial cells isolated and propagated by conditional reprogrammed cell culture. Oncotarget 9:11503-11514

Jonsdottir HR, Marti S, Geerts D, Rodriguez R, Thiel V, Dijkman R (2019) Establishment of primary transgenic human airway epithelial cell cultures to study respiratory virus-host interactions. Viruses 11:1

Kim YI, Kim SG, Kim SM, Kim EH, Park SJ, Yu KM, Chang JH, Kim EJ, Lee S, Casel MAB, Um J, Song MS, Jeong HW, Lai VD, Kim Y, Chin BS, Park JS, Chung KH, Foo SS, Poo H, Mo IP, Lee OJ, Webby RJ, Jung JU, Choi YK (2020) Infection and rapid transmission of SARS-CoV-2 in ferrets. Cell Host Microbe. https://doi.org/10.1016/j.chom.2020.03.023

Klingelhutz AJ, Roman A (2012) Cellular transformation by human papillomaviruses: lessons learned by comparing high- and lowrisk viruses. Virology 424:77-98

Kong SL, Chui P, Lim B, Salto-Tellez M (2009) Elucidating the molecular physiopathology of acute respiratory distress syndrome in severe acute respiratory syndrome patients. Virus Res 145:260-269

Kotha PL, Sharma P, Kolawole AO, Yan R, Alghamri MS, Brockman TL, Gomez-Cambronero J, Excoffon KJ (2015) Adenovirus entry from the apical surface of polarized epithelia is facilitated by the host innate immune response. PLoS Pathog 11:e1004696

Krawczyk E, Hong SH, Galli S, Trinh E, Wietlisbach L, Misiukiewicz SF, Tilan JU, Chen YS, Schlegel R, Kitlinska J (2020) Murine neuroblastoma cell lines developed by conditional reprogramming preserve heterogeneous phenotypes observed in vivo. Lab Invest 100:38-51

Ksiazek TG, Erdman D, Goldsmith CS, Zaki SR, Peret T, Emery S, Tong S, Urbani C, Comer JA, Lim W, Rollin PE, Dowell SF, Ling AE, Humphrey CD, Shieh WJ, Guarner J, Paddock CD, Rota P, Fields B, DeRisi J, Yang JY, Cox N, Hughes JM, LeDuc JW, Bellini WJ, Anderson LJ, Group SW (2003) A novel coronavirus associated with severe acute respiratory syndrome. N Engl J Med 348:1953-1966

LaRanger R, Peters-Hall JR, Coquelin M, Alabi BR, Chen CT, Wright WE, Shay JW (2018) Reconstituting mouse lungs with conditionally reprogrammed human bronchial epithelial cells. Tissue Eng Part A 24:559-568

Li X, Vargas Buonfiglio LG, Adam RJ, Stoltz DA, Zabner J, Comellas AP (2017) Cystic fibrosis transmembrane conductance regulator potentiation as a therapeutic strategy for pulmonary edema: a proof-of-concept study in pigs. Crit Care Med 45:e1240-e1246

Liu X (2019) Re: Kimmo Kettunen, Peter J. Bostrom, Tarja Lamminen, et al. Personalized Drug Sensitivity Screening for Bladder Cancer Using Conditionally Reprogrammed Patientderived Cells. Eur Urol. In press. https://doi.org/10.1016/j.eururo.2019.06.016: Can Patient-derived Cancer Models Change the Costliest Cancer Type? Eur Urol. https://doi.org/10.1016/ j.eururo.2019.09.014

Liu X, Yuan H, Fu B, Disbrow GL, Apolinario T, Tomaic V, Kelley ML, Baker CC, Huibregtse J, Schlegel R (2005) The E6AP ubiquitin ligase is required for transactivation of the hTERT promoter by the human papillomavirus E6 oncoprotein. J Biol Chem 280:10807-10816

Liu X, Disbrow GL, Yuan H, Tomaic V, Schlegel R (2007) Myc and human papillomavirus type $16 \mathrm{E} 7$ genes cooperate to immortalize human keratinocytes. J Virol 81:12689-12695

Liu X, Dakic A, Chen R, Disbrow GL, Zhang Y, Dai Y, Schlegel R (2008) Cell-restricted immortalization by human papillomavirus correlates with telomerase activation and engagement of the hTERT promoter by Myc. J Virol 82:11568-11576

Liu X, Dakic A, Zhang Y, Dai Y, Chen R, Schlegel R (2009) HPV E6 protein interacts physically and functionally with the cellular telomerase complex. Proc Natl Acad Sci U S A 106:18780-18785

Liu X, Ory V, Chapman S, Yuan H, Albanese C, Kallakury B, Timofeeva OA, Nealon C, Dakic A, Simic V, Haddad BR, Rhim JS, Dritschilo A, Riegel A, McBride A, Schlegel R (2012) ROCK inhibitor and feeder cells induce the conditional reprogramming of epithelial cells. Am J Pathol 180:599-607

Liu X, Krawczyk E, Suprynowicz FA, Palechor-Ceron N, Yuan H, Dakic A, Simic V, Zheng YL, Sripadhan P, Chen C, Lu J, Hou TW, Choudhury S, Kallakury B, Tang DG, Darling T, Thangapazham R, Timofeeva O, Dritschilo A, Randell SH, Albanese C, Agarwal S, Schlegel R (2017) Conditional reprogramming and long-term expansion of normal and tumor cells from human biospecimens. Nat Protoc 12:439-451

Lu H, Stratton CW, Tang YW (2020) Outbreak of pneumonia of unknown etiology in Wuhan, China: the mystery and the miracle. J Med Virol 92:401-402

Mahajan AS, Sugita BM, Duttargi AN, Saenz F, Krawczyk E, McCutcheon JN, Fonseca AS, Kallakury B, Pohlmann P, Gusev Y, Cavalli LR (2017) Genomic comparison of early-passage conditionally reprogrammed breast cancer cells to their corresponding primary tumors. PLoS ONE 12:e0186190

Martini A, Sfakianos JP, Galsky MD (2019) Conditionally Reprogrammed Patient-derived Cells: a Step Forward Towards Personalized Medicine? Eur Urol 76:435-436

Martinovich KM, Iosifidis T, Buckley AG, Looi K, Ling KM, Sutanto EN, Kicic-Starcevich E, Garratt LW, Shaw NC, Montgomery S, Lannigan FJ, Knight DA, Kicic A, Stick SM (2017) Conditionally reprogrammed primary airway epithelial cells maintain morphology, lineage and disease specific functional characteristics. Sci Rep 7:17971

Mimoto R, Fushimi A, Kazama T, Nogi H, Takeyama H (2018) Conditional Reprogramming Cells Are Novel Tools for Drug Response Assay and the Development of Personalized Medicine in Luminal-B Breast Cancer. J Am Coll Surg 227:e79

Mondal AM, Ma AH, Li G, Krawczyk E, Yuan R, Lu J, Schlegel R, Stamatakis L, Kowalczyk KJ, Philips GK, Pan CX, Liu X (2019) 
Fidelity of a PDX-CR model for bladder cancer. Biochem Biophys Res Commun 517:49-56

Moorefield EC, Blue RE, Quinney NL, Gentzsch M, Ding S (2018) Generation of renewable mouse intestinal epithelial cell monolayers and organoids for functional analyses. BMC Cell Biol 19:15

Mou H, Vinarsky V, Tata PR, Brazauskas K, Choi SH, Crooke AK, Zhang B, Solomon GM, Turner B, Bihler H, Harrington J, Lapey A, Channick C, Keyes C, Freund A, Artandi S, Mense M, Rowe S, Engelhardt JF, Hsu YC, Rajagopal J (2016) Dual SMAD Signaling Inhibition Enables Long-Term Expansion of Diverse Epithelial Basal Cells. Cell Stem Cell 19:217-231

Mullenders J, de Jongh E, Brousali A, Roosen M, Blom JPA, Begthel $\mathrm{H}$, Korving J, Jonges T, Kranenburg O, Meijer R, Clevers HC (2019) Mouse and human urothelial cancer organoids: a tool for bladder cancer research. Proc Natl Acad Sci U S A 116:4567-4574

Nicolas N, Upadhyay G, Velena A, Kallakury B, Rhim JS, Dritschilo A, Jung M (2019) African-American prostate normal and cancer cells for health disparities research. Adv Exp Med Biol 1164:101-108

Palechor-Ceron N, Suprynowicz FA, Upadhyay G, Dakic A, Minas T, Simic V, Johnson M, Albanese C, Schlegel R, Liu X (2013) Radiation induces diffusible feeder cell factor(s) that cooperate with ROCK inhibitor to conditionally reprogram and immortalize epithelial cells. Am J Pathol 183:1862-1870

Palechor-Ceron N, Krawczyk E, Dakic A, Simic V, Yuan H, Blancato J, Wang W, Hubbard F, Zheng YL, Dan H, Strome S, Cullen K, Davidson B, Deeken JF, Choudhury S, Ahn PH, Agarwal S, Zhou X, Schlegel R, Furth PA, Pan CX, Liu X (2019) Conditional Reprogramming for Patient-Derived Cancer Models and Next-Generation Living Biobanks. Cells 8:1

Papapetrou EP (2016) Patient-derived induced pluripotent stem cells in cancer research and precision oncology. Nat Med 22:1392-1401

Peters-Hall JR, Coquelin ML, Torres MJ, LaRanger R, Alabi BR, Sho S, Calva-Moreno JF, Thomas PJ, Shay JW (2018) Long-term culture and cloning of primary human bronchial basal cells that maintain multipotent differentiation capacity and CFTR channel function. Am J Physiol Lung Cell Mol Physiol 315:L313-L327

Puca L, Bareja R, Prandi D, Shaw R, Benelli M, Karthaus WR, Hess J, Sigouros M, Donoghue A, Kossai M, Gao D, Cyrta J, Sailer V, Vosoughi A, Pauli C, Churakova Y, Cheung C, Deonarine LD, McNary TJ, Rosati R, Tagawa ST, Nanus DM, Mosquera JM, Sawyers CL, Chen Y, Inghirami G, Rao RA, Grandori C, Elemento O, Sboner A, Demichelis F, Rubin MA, Beltran H (2018) Patient derived organoids to model rare prostate cancer phenotypes. Nat Commun 9:2404

Reynolds SD, Rios C, Wesolowska-Andersen A, Zhuang Y, Pinter M, Happoldt C, Hill CL, Lallier SW, Cosgrove GP, Solomon GM, Nichols DP, Seibold MA (2016) Airway progenitor clone formation is enhanced by Y-27632-dependent changes in the transcriptome. Am J Respir Cell Mol Biol 55:323-336

Roberts N, Al Mubarak R, Francisco D, Kraft M, Chu HW (2018) Comparison of paired human nasal and bronchial airway epithelial cell responses to rhinovirus infection and IL-13 treatment. Clin Transl Med 7:13

Sachs N, de Ligt J, Kopper O, Gogola E, Bounova G, Weeber F, Balgobind AV, Wind K, Gracanin A, Begthel H, Korving J, van Boxtel R, Duarte AA, Lelieveld D, van Hoeck A, Ernst RF, Blokzijl F, Nijman IJ, Hoogstraat M, van de Ven M, Egan DA, Zinzalla V, Moll J, Boj SF, Voest EE, Wessels L, van Diest PJ, Rottenberg S, Vries RGJ, Cuppen E, Clevers H (2018) A living biobank of breast cancer organoids captures disease heterogeneity. Cell 172(373-386):e310
Saenz FR, Ory V, AlOtaiby M, Rosenfield S, Furlong M, Cavalli LR, Johnson MD, Liu X, Schlegel R, Wellstein A, Riegel AT (2014) Conditionally reprogrammed normal and transformed mouse mammary epithelial cells display a progenitor-cell-like phenotype. PLoS One 9:e97666

Senft D, Leiserson MDM, Ruppin E, Ronai ZA (2017) Precision oncology: the road ahead. Trends Mol Med 23:874-898

Shay JW, Peters-Hall JR, Min J, Tedone E, Sho S, Siteni S, Mender I (2018) Human lung epithelial cells divide $>200$ population doublings without engaging a telomere maintenance mechanism. bioRxiv. https://doi.org/10.1101/474270:474270

Sheahan TP, Sims AC, Graham RL, Menachery VD, Gralinski LE, Case JB, Leist SR, Pyrc K, Feng JY, Trantcheva I, Bannister R, Park Y, Babusis D, Clarke MO, Mackman RL, Spahn JE, Palmiotti CA, Siegel D, Ray AS, Cihlar T, Jordan R, Denison MR, Baric RS (2017) Broad-spectrum antiviral GS-5734 inhibits both epidemic and zoonotic coronaviruses. Sci Transl Med 9:1

Sheahan TP, Sims AC, Zhou S, Graham RL, Pruijssers AJ, Agostini ML, Leist SR, Schafer A, Dinnon KH 3rd, Stevens LJ, Chappell JD, Lu X, Hughes TM, George AS, Hill CS, Montgomery SA, Brown AJ, Bluemling GR, Natchus MG, Saindane M, Kolykhalov AA, Painter G, Harcourt J, Tamin A, Thornburg NJ, Swanstrom R, Denison MR, Baric RS (2020) An orally bioavailable broad-spectrum antiviral inhibits SARS-CoV-2 in human airway epithelial cell cultures and multiple coronaviruses in mice. Sci Transl Med 12:1

Shi J, Wen Z, Zhong G, Yang H, Wang C, Huang B, Liu R, He X, Shuai L, Sun Z, Zhao Y, Liu P, Liang L, Cui P, Wang J, Zhang X, Guan Y, Tan W, Wu G, Chen H, Bu Z (2020) Susceptibility of ferrets, cats, dogs, and other domesticated animals to SARScoronavirus 2. Science. https://doi.org/10.1126/science.abb7015

Singhal T (2020) A review of coronavirus disease-2019 (COVID-19). Indian J Pediatr. https://doi.org/10.1007/s12098-020-03263-6

Smits SL, van den Brand JM, de Lang A, Leijten LM, van Ijcken WF, van Amerongen G, Osterhaus AD, Andeweg AC, Haagmans BL (2011) Distinct severe acute respiratory syndrome coronavirusinduced acute lung injury pathways in two different nonhuman primate species. J Virol 85:4234-4245

Su S, Di Poto C, Roy R, Liu X, Cui W, Kroemer A, Ressom HW (2019) Highlight article: long-term culture and characterization of patient-derived primary hepatocytes using conditional reprogramming. Exp Biol Med (Maywood) 244:857-864

Suprynowicz FA, Upadhyay G, Krawczyk E, Kramer SC, Hebert JD, Liu X, Yuan H, Cheluvaraju C, Clapp PW, Boucher RC Jr, Kamonjoh CM, Randell SH, Schlegel R (2012) Conditionally reprogrammed cells represent a stem-like state of adult epithelial cells. Proc Natl Acad Sci USA 109:20035-20040

To KK, Tsang OT, Leung WS, Tam AR, Wu TC, Lung DC, Yip CC, Cai JP, Chan JM, Chik TS, Lau DP, Choi CY, Chen LL, Chan WM, Chan KH, Ip JD, Ng AC, Poon RW, Luo CT, Cheng VC, Chan JF, Hung IF, Chen Z, Chen H, Yuen KY (2020) Temporal profiles of viral load in posterior oropharyngeal saliva samples and serum antibody responses during infection by SARS-CoV-2: an observational cohort study. Lancet Infect Dis. https://doi.org/ 10.1016/S1473-3099(20)30196-1

Tseng CT, Tseng J, Perrone L, Worthy M, Popov V, Peters CJ (2005) Apical entry and release of severe acute respiratory syndromeassociated coronavirus in polarized Calu-3 lung epithelial cells. J Virol 79:9470-9479

Walls AC, Park YJ, Tortorici MA, Wall A, McGuire AT, Veesler D (2020) Structure, Function, and Antigenicity of the SARS-CoV2 Spike Glycoprotein. Cell. https://doi.org/10.1016/j.cell.2020. 02.058

Walters BJ, Diao S, Zheng F, Walters BJ, Layman WS, Zuo J (2015) Pseudo-immortalization of postnatal cochlear progenitor cells 
yields a scalable cell line capable of transcriptionally regulating mature hair cell genes. Sci Rep 5:17792

Wan Y, Shang J, Graham R, Baric RS, Li F (2020) Receptor recognition by the novel coronavirus from wuhan: an analysis based on decade-long structural studies of SARS coronavirus. J Virol 94:1

Wang L, Ye L, Wei G, Chen Y, Ye L, Wu X, Zeng Z, Wang Y, Yin G, Long X, Li H (2018) Conditional reprogrammed human limbal epithelial cells represent a novel in vitro cell model for drug responses. Biochem Biophys Res Commun 499:735-742

Wang T, Du Z, Zhu F, Cao Z, An Y, Gao Y, Jiang B (2020) Comorbidities and multi-organ injuries in the treatment of COVID-19. Lancet. https://doi.org/10.1016/S01406736(20)30558-4

Weeber F, Ooft SN, Dijkstra KK, Voest EE (2017) Tumor organoids as a pre-clinical cancer model for drug discovery. Cell Chem Biol 24:1092-1100

Wolf S, Perez GF, Mukharesh L, Isaza N, Preciado D, Freishtat RJ, Pillai D, Rose MC, Nino G (2017) Conditional reprogramming of pediatric airway epithelial cells: a new human model to investigate early-life respiratory disorders. Pediatr Allergy Immunol 28:810-817

Wolfel R, Corman VM, Guggemos W, Seilmaier M, Zange S, Muller MA, Niemeyer D, Jones TC, Vollmar P, Rothe C, Hoelscher M, Bleicker T, Brunink S, Schneider J, Ehmann R, Zwirglmaier K, Drosten C, Wendtner C (2020) Virological assessment of hospitalized patients with COVID-2019. Nature. https://doi.org/ 10.1038/s41586-020-2196-x

World Health Organization (WHO) (2019) Middle east respiratory syndrome coronavirus (MERS-CoV). https://www.who.int/emer gencies/mers-cov/en/

World Health Organization (WHO) (2020) Coronavirus disease 2019 (COVID-19) Situation Report-58. 18 March 2020. https:// www.who.int/emergencies/diseases/novel-coronavirus-2019/ situation-reports

Wrapp D, Wang N, Corbett KS, Goldsmith JA, Hsieh CL, Abiona O, Graham BS, McLellan JS (2020) Cryo-EM structure of the 2019-nCoV spike in the prefusion conformation. Science 367:1260-1263

Wu Z, McGoogan JM (2020) Characteristics of and Important Lessons From the Coronavirus Disease 2019 (COVID-19) Outbreak in China: summary of a Report of 72314 Cases From the Chinese Center for Disease Control and Prevention. JAMA. https://doi.org/10.1001/jama.2020.2648

Xinaris C (2019) Organoids for replacement therapy: expectations, limitations and reality. Curr Opin Organ Transplant 24:555-561

Yang S, Cao P, Du P, Wu Z, Zhuang Z, Yang L, Yu X, Zhou Q, Feng X, Wang X, Li W, Liu E, Chen J, Chen Y, He D (2020a) Early estimation of the case fatality rate of COVID-19 in mainland China: a data-driven analysis. Ann Transl Med 8:128

Yang X, Yu Y, Xu J, Shu H, Xia J, Liu H, Wu Y, Zhang L, Yu Z, Fang M, Yu T, Wang Y, Pan S, Zou X, Yuan S, Shang Y (2020b) Clinical course and outcomes of critically ill patients with SARS-CoV-2 pneumonia in Wuhan, China: a single-centered, retrospective, observational study. Lancet Respir Med. https:// doi.org/10.1016/S2213-2600(20)30079-5

Ye G, Pan Z, Pan Y, Deng Q, Chen L, Li J, Li Y, Wang X (2020) Clinical characteristics of severe acute respiratory syndrome coronavirus 2 reactivation. J Infect. https://doi.org/10.1016/j.jinf. 2020.03.001

Yu F, Lu Y, Tao L, Jiang YY, Lin DC, Wang L, Petersson F, Yoshiyama H, Koeffler PH, Goh BC, Loh KS (2017) Non- malignant epithelial cells preferentially proliferate from nasopharyngeal carcinoma biopsy cultured under conditionally reprogrammed conditions. Sci Rep 7:17359

Yuan H, Myers S, Wang J, Zhou D, Woo JA, Kallakury B, Ju A, Bazylewicz M, Carter YM, Albanese C, Grant N, Shad A, Dritschilo A, Liu X, Schlegel R (2012) Use of reprogrammed cells to identify therapy for respiratory papillomatosis. N Engl J Med 367:1220-1227

Yuan H, Krawczyk E, Blancato J, Albanese C, Zhou D, Wang N, Paul S, Alkhilaiwi F, Palechor-Ceron N, Dakic A, Fang S, Choudhary S, Hou TW, Zheng YL, Haddad BR, Usuda Y, Hartmann D, Symer D, Gillison M, Agarwal S, Wangsa D, Ried T, Liu X, Schlegel R (2017) HPV positive neuroendocrine cervical cancer cells are dependent on Myc but not E6/E7 viral oncogenes. Sci Rep 7:45617

Yue J, Shukla R, Accardi R, Zanella-Cleon I, Siouda M, Cros MP, Krutovskikh V, Hussain I, Niu Y, Hu S, Becchi M, Jurdic P, Tommasino M, Sylla BS (2011) Cutaneous human papillomavirus type 38 E7 regulates actin cytoskeleton structure for increasing cell proliferation through CK2 and the eukaryotic elongation factor 1A. J Virol 85:8477-8494

Zaki AM, van Boheemen S, Bestebroer TM, Osterhaus AD, Fouchier RA (2012) Isolation of a novel coronavirus from a man with pneumonia in Saudi Arabia. N Engl J Med 367:1814-1820

Zhang C, Lee HJ, Shrivastava A, Wang R, McQuiston TJ, Challberg SS, Pollok BA, Wang T (2018a) Long-term in vitro expansion of epithelial stem cells enabled by pharmacological inhibition of PAK1-ROCK-Myosin II and TGF-beta signaling. Cell Rep 25(598-610):e595

Zhang Z, Bai Q, Chen Y, Ye L, Wu X, Long X, Ye L, Liu J, Li H (2018b) Conditionally reprogrammed human normal bronchial epithelial cells express comparable levels of cytochromes p450 and are sensitive to $\mathrm{BaP}$ induction. Biochem Biophys Res Commun 503:2132-2138

Zhang C, Shi L, Wang FS (2020) Liver injury in COVID-19: management and challenges. Lancet Gastroenterol Hepatol. https://doi.org/10.1016/S2468-1253(20)30057-1

Zhou C, Gao C, Xie Y, Xu M (2020a) COVID-19 with spontaneous pneumomediastinum. Lancet Infect Dis. https://doi.org/10.1016/ S1473-3099(20)30156-0

Zhou F, Yu T, Du R, Fan G, Liu Y, Liu Z, Xiang J, Wang Y, Song B, Gu X, Guan L, Wei Y, Li H, Wu X, Xu J, Tu S, Zhang Y, Chen H, Cao B (2020b) Clinical course and risk factors for mortality of adult inpatients with COVID-19 in Wuhan, China: a retrospective cohort study. Lancet. https://doi.org/10.1016/ S0140-6736(20)30566-3

Zhou P, Yang XL, Wang XG, Hu B, Zhang L, Zhang W, Si HR, Zhu Y, Li B, Huang CL, Chen HD, Chen J, Luo Y, Guo H, Jiang RD, Liu MQ, Chen Y, Shen XR, Wang X, Zheng XS, Zhao K, Chen QJ, Deng F, Liu LL, Yan B, Zhan FX, Wang YY, Xiao GF, Shi ZL (2020c) A pneumonia outbreak associated with a new coronavirus of probable bat origin. Nature 579:270-273

Zhu Y, Yang Y, Guo J, Dai Y, Ye L, Qiu J, Zeng Z, Wu X, Xing Y, Long X, Wu X, Ye L, Wang S, Li H (2017) Ex vivo 2D and 3D HSV-2 infection model using human normal vaginal epithelial cells. Oncotarget 8:15267-15282

Zou L, Ruan F, Huang M, Liang L, Huang H, Hong Z, Yu J, Kang M, Song Y, Xia J, Guo Q, Song T, He J, Yen HL, Peiris M, Wu J (2020) SARS-CoV-2 Viral Load in Upper Respiratory Specimens of Infected Patients. N Engl J Med. https://doi.org/10.1056/ NEJMc2001737 